\title{
HUNTING METHODISTS KILL 1,600 POUNDS OF BUFFALO MEAT IN KOSSUTH COUNTY
}

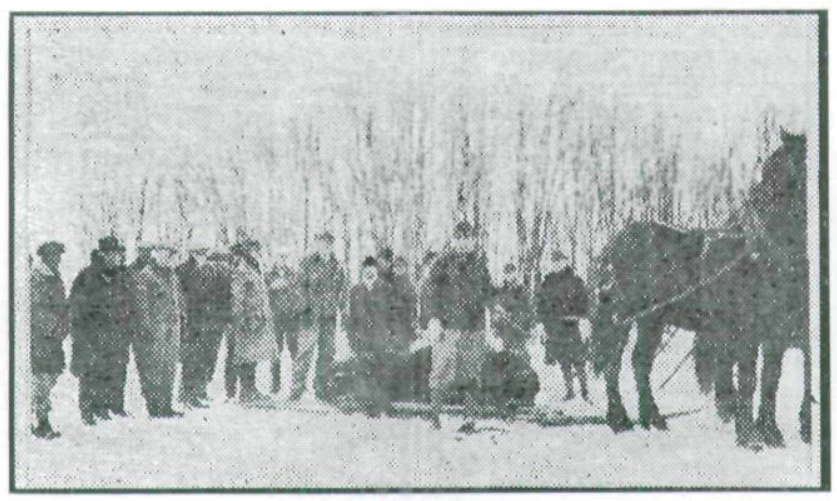

Church Will Get Funds

From SALE OF

GAME

Ten good Methodists went ahunting last week - and brought back 1,600 pounds of buffalo, shot in the wilds of Kossuth County.

F. C. Upton of the Chicago Joint Stock Land bank was host to the group and Grace Methodist Sunday school will be beneficiary of the hunt. For Mr. Upton, who is superintendent of the Sunday school, has placed the wild meat on sale, and the entire proceeds will be turned over to the Sunday school. Dr. A. A. Brooks, the Rev. Dilman Smith, W. H. Tutt, Paul Payne, C. F. Chambers, Dr. C. F. Spring, F. R. Hubbard, A. L. Johnson, John Rusterholtz and Mr. Upton journeyed to the old Lenander ranch near Swea City last Thursday, where two buffalo were known to roam at will. The farm was recently taken over by Mr. Upton and the edict had gone out that the last two of the vanishing herds of the country would have to go.

Mr. Upton was designated as the crack shot of the party, but several of the group had guns for fear Mr. Upton should fail, and a large audience of nearby farmers was there to help with the destruction of the last remnants of the herd. 


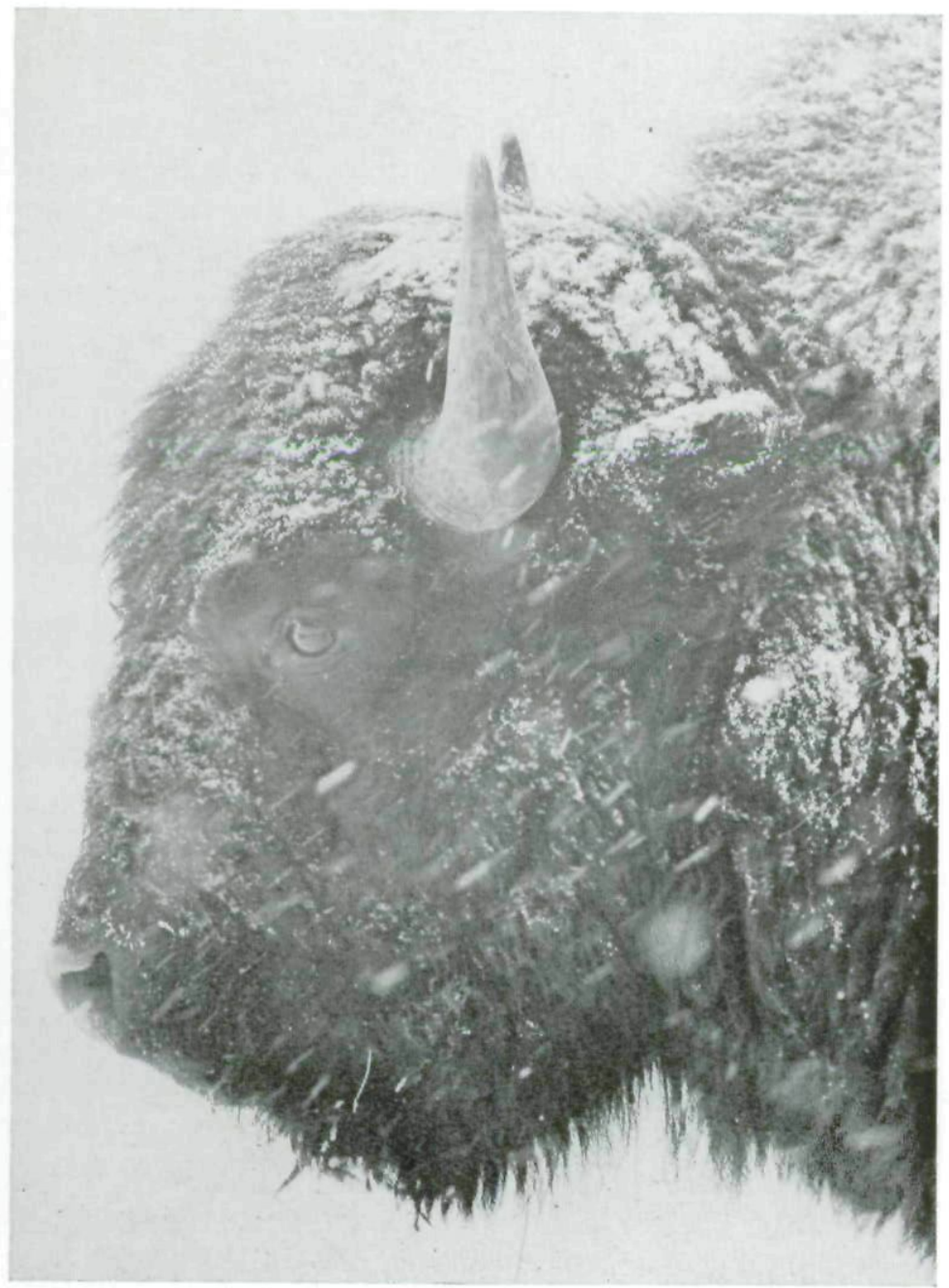

The cow dropped dead at the first shot, but the bull, true to his ancestors' blood, fought his death and charged to within twenty-five feet of Mr. Upton before a second shot put him down.

The Lenander ranch formerly sheltered the largest herd of buffalo in northern Iowa, but the numbers had gradually decreased until but two remained. When dressed the meat, 
weighing 1,600 pounds, was loaded on a truck and brought to Des Moines where it is in cold storage.

Mrs. A. A. Brooks and Mrs. Upton, wives of the hunters, surprised the entire group of marksmen with a buffalo dinner Thursday night at the Brooks home. The two animals were fat from a diet of grain and the meat was pronounced delicious.

From the Des Moines Register, February, 1927

\title{
CORN MEAL RECIPES*
}

\author{
IOWA WAFFLES \\ $1 \frac{1}{2}$ pints of boiling water. \\ 1 pint corn meal. \\ 1 pint flour. \\ $1 / 2$ pint butter-milk or sour cream. \\ $2 / 3$ pint of sweet milk. \\ 4 eggs. \\ 1 heaping table spoon of butter. \\ 1 tea spoon salt. \\ 1 tea spoon soda. \\ 1 tea spoon cream tarter.
}

Make the corn meal into mush in the usual way, with the boiling water, and while hot stir in the butter and salt. Cook the mush half an hour. Set the mush aside to cool. Meanwhile beat separately the eggs till very light; next beat into the mush the sour cream and soda, then the yolks of eggs alternating with the sweet milk, and work in gradually the flour, in which the cream tartar has been sifted.

An hour should be allowed for making these waffles. Have

- From Indian Corn as Human Food, by Mary S. Scott, Nevada, Iowa (Payne \& Son) 1889, pp. 80-83. 
Copyright of Annals of Iowa is the property of State of Iowa, by \& through the State Historical Society of Iowa and its content may not be copied or emailed to multiple sites or posted to a listserv without the copyright holder's express written permission. However, users may print, download, or email articles for individual use. 